\title{
Physiological Quality of Rice and Soybean Seeds Produced Under Hydric Stress in Greenhouse
}

\author{
Ruddy A. V. Escalera ${ }^{1}$, João R. Pimentel ${ }^{1}$, Cristian Troyjack ${ }^{1}$, Ivan R. Carvalho ${ }^{1}$, Vinícius J. Szareski ${ }^{1}$, \\ Márcio Peter ${ }^{1}$, Suelen M. Fachi ${ }^{2}$, Francielen L. da Silva ${ }^{1}$, Liriana L. Fonseca ${ }^{1}$, Lanes B. A. Jaques ${ }^{2}$, \\ Giordano G. Conte ${ }^{1}$, Francisco A. Villela ${ }^{1}$, Tiago Z. Aumonde ${ }^{1} \&$ Tiago Pedó \\ ${ }^{1}$ Federal University of Pelotas, Capão do Leão, Rio Grande do Sul, Brazil \\ ${ }^{2}$ Federal University of Santa Maria, Rio Grande do Sul, Brazil \\ Correspondence: Ivan Ricardo Carvalho, Universidade Federal de Pelotas, Rio Grande do Sul, Brazil, Tel: \\ 55-9640-8757. E-mail: carvalho.irc@gmail.com
}

Received: December 4, $2018 \quad$ Accepted: March 20, $2019 \quad$ Online Published: July 31, 2019

doi:10.5539/jas.v11n12p22 URL: https://doi.org/10.5539/jas.v11n12p22

\begin{abstract}
The hydric resources are primordial for plants growth and development, under conditions where the growing environment express hydric shortage. These conditions can directly or indirectly affect development, the formation of new organs, yield and quality seeds. The study aimed to evaluate the physiological quality of rice and soybean seeds, produced under hydric restriction. Experiment 1: for rice, the scheme was completely randomized with four repetitions, the treats of hydric restrictions were applied in the periods of $0,24,48,72$ hours at the phenological stage of filling seeds. Experiment 2: for soybean, the scheme was completely randomized, conducted in factorial scheme, four replicates with four hydric restriction periods of $0,24,48$ and 72 hours, at the phenological stage of filling seeds. It was verified that as the hydric restriction hours increase, at the rice seeds filling, the physiologic quality is affected, the higher effect occurred at 72 hours of restriction. While at the soybean seeds production it was not verified such effects, only the thousand seeds mass was negatively affected. The physiological quality of rice seeds were more affected, when compared to soybean seeds submitted to the same treats of hydric stress.
\end{abstract}

Keywords: Oryza sativa, Glycine max, seed production, hydric restriction, quality seeds

\section{Introduction}

The hydric resources are primordial for plants growth and development. Under conditions where the growing environment express hydric shortage, the plant can express phenotypic modifications, as well harm cells and photosynthetic functioning, and reduce plants survival at field conditions (Fiorenze et al., 2011).

The hydric stress occurs due to water loss to the environment thru evapotranspiration, and in higher amounts than water absorption by root structures (Tavares et al., 2013a), these conditions can harm the normal development of crops in the initial stages (Bonfim-Silva et al., 2011), also the losses in seeds yield (Costa, 2008; Lobato, 2008). The seeds with higher quality have higher physiologic potential and can tolerate some abiotic stresses, as the hydric limitation, decreasing the probability to reduce the productivity and the field production of seeds (Tavares et al., 2013a; Szareski et al., 2018a).

At the first phenological stages, the absence of water availability can affect directly or indirectly the formation of new organs, such as the magnitude of non-reproductive and productive nodes, legumes and seeds (Tavarees et al., 2013b). Many are de factors that can influence these characters, such as growing environments and genetic effects. Such influences directly affect the chemical proprieties and seed quality, lipid and protein concentration (Avila et al., 2007).

Many researches are mentioned on the effects of hydric restriction applied to different vegetative and reproductive stages, where Such Miorini et al. (2011) evaluated the influence of water suppress, in comparison with irrigation in all and none growing stages of common beans (Miorini et al., 2012). In addition, Catuchi et al. (2012) evaluated the interference of potassium fertilizing in physiologic parameters of two soybean cultivars, under hydric restriction (Catuchi et al., 2012), as well as Artigiani et al. (2012), which aimed to evaluate yield compounds, productivity and industrial quality of rice grains of the cultivar BRS Primavera, in function of the 
silicon application combined with broadcast nitrogen fertilizing, in dry and irrigated conditions (Artigiani et al., 2012). Harming the yield, although it is not well known the effects on the seeds quality for sowing, or on nutritional quality, a hydric deficiency in the flowering or grains filling can cause low fecundation, also an irregular seeds formation.

The informations of possible effects caused by hydric deficiency in seeds production can provide informations to predict if a batch of seeds will be fit for commercialization (Szareski et al., 2018b). As well,it can infer in the answer of physiologic quality levels of the analyzed seeds and the importance of the hydric request in the reproductive stage for seeds production, needing a more accurate information on the effects in the quality of seeds originated from plants under stresses. In this contexto, the main purpose of this study was to evaluate the physiologic quality of rice and soybean seeds, produced under hydric restriction.

\section{Material and Methods}

The experiment was conducted in the municipality of Capão do Leão-RS ( $31^{\circ} 52^{\prime}$ S; 52 $22^{\circ}$ W) in $2015 / 2016$. Situated at six meters of altitude, the greenhouse is a gable model, coated with polycarbonate and disposed in the north-south direction and temperature and air relative humidity controlled, belonging to the Federal University of Pelotas. The climate in the region is characterized as temperate with well-distributed rainfall and warm summer, being Cfa type, by Köppen classification.

Experiment 1: For rice, the scheme was completely randomized with four repetitions, disposed in containers and constant flooding. The treats of hydric restrictions were applied in the periods of $0,24,48,72$ hours, in the R6 stage, which comprehends the seeds filling stage (Agitec). The seeds were harvested, dried out at to $13 \%$ of humidity, and after stored in paper packing at ambient temperature.

Experiment 2: For the soybean, it was used seeds of the cultivar BMX Potência RR, disposed in black polyethylene containers with 10 liters of capacity, containing horizon A soil as substrate, prevenient of a Solodic Planosol, previously adjusted according to the soul analysis based in the Fertilizing Manual ${ }^{12}$. The design was completely randomized, conducted in factorial scheme, four replicates with four hydric restriction periods $(0,24$, 48 and 72 hours), each experimental unit was composed of a bucket with four plants each. The treats were applied at the R5 stage (Fehr, 1977), which comprehends the seeds filling stage. It was applied the hydric restriction at the periods $0,24,48$ and 72 hours without irrigation, corresponding to the irrigation restriction treat. An additional treat was represented by the maintenance of the field capacity, which was determined from the tension table methodology (Embrapa, 1997). The seeds where harvested, dried out to $12 \%$ humidity and stored in cold chamber at $16{ }^{\circ} \mathrm{C}$.

Experimental details: For both cultures, the measured characters were:

Field emergence $(E)$ : The emergence test $(E)$ was performed in trays at the greenhouse, using soil as substrate, and used 50 seeds for replicate manually sowed. The emergence percentage was obtained by the emerged seedlings counting at the twentieth first day after seedling.

Foliage area (FA): The foliage area was measured using a photoelectric device (Area Meter, modl LI-3100 from Li-corLtda), and the results expressed in square centimeters.

Seedlings dry mass: It is obtained from the mass of four subsamples of 10 seedlings, previously divided in shoot (SDM), leaves (LDM) and radicle (RDM), at the end of the germination and emergence test in greenhouse at 21 days. The seedlings organs are separately conditioned in craft envelopes and submitted to drying using kiln with forced ventilation, under $70{ }^{\circ} \mathrm{C}$ temperature until constant mass, for 72 hours. The results are expressed in milligrams of $\operatorname{shoot}^{-1}$ and radicle ${ }^{-1}$.

Thousand seeds mass (TSM): Determined by counting of 8subsamples of 100 seeds of each experimental plot, obtained randomly, which were weighed. The values were expressed in grams (Brasil, 2009).

Esterase isoenzyme: It was randomly collected 10 seedlings for the vegetal material extraction that were macerated in porcelain bowl. The esterase isoenzyme (ES) expression was determined by the vertical electrophorese system in polyacrylamide gel.

From every macerated treat, it was collected $200 \mathrm{mg}$ of vegetal extract and was conditioned in Heppendorf tubes, added extracting solution (buffer gel- $0.15 \%$ of 2-mercaptoethanol) in the $1: 3$ proportion $(\mathrm{p} / \mathrm{v})$. The vertical electrophorese system was built with $7 \%$ polyacrylamide gels, with $20 \mu \mathrm{L}$ of vegetal material, in orifices made with an acrylic comb. The gels where conditioned in electrophoretic cubes with movement, maintained in ambient temperature for two hours, until the front run was formed by the bromophenol blue and achieved nine centimeters from the application point. The isoenzymatic patterns were realized by the buffer system described 
(Scandalios et al., 1969). The interpretation of the results werebased on the visual analysis of the electrophoresis gels, considering the presence or absence, and the quantification of bands realized with the Gel-Pro Analyzer 3.1 software.

Statistical analysis: The data were submitted touni directional variance analysis of generalized linear models, in the presence of significance, it was proceeded the regression analysis, and the means compared by Tukey test at $5 \%$ probability.

\section{Results and Discussion}

It is possible to observe, at the variance analysis (Table 1), that the variables field emergence (E), foliage area (FA), leaves dry mass (LDM) and thousand seeds mass (TSM) presented significant effect at the various hydric restriction levels. While for the variables shoot dry matter (SDM) and root dry matter (RDM), did not present significant difference at the different hydric restriction levels.

The thousand seeds mass (TSM), according to Figure 1A, had a decreasing quadratic behavior, starting to lose weight from the treat of 24 hours of water restriction. The treat of 72 hours of restriction presented lower TSM, at the Figure 1B, is observed that AF presented a decrease due to the higher amount of restriction hours, the same for seeds emergence, which the lowest value was found at 72 hours of hydric restriction(Figure 1C). The dry mass of leaves (Figure 1D)had a slighly decrease when submitted to higher period of hydric restriction, in this manner, as in the main variables, it was evidence lower dry matter amount when submitted to 72 hours of restriction. The performance of thousand seeds mass, foliage area, emergence and leaves dry mass (Figure 1), were negatively affected in a linear and/or quadratic manner at the higher hydric restriction.

Table 1. Variance analysis of experiment 1 (Rice) for the fator hydric restriction period for the characters of Emergence (E), Foliage Area (FA), Shoot Dry Matter (SDM), Leaves Dry Mass (LDM), Root Dry Matter (RDM) and Thousand Seeds Mass (TSM)

\begin{tabular}{llllllll}
\hline \multirow{2}{*}{ VF } & \multirow{2}{*}{ DF } & \multicolumn{5}{c}{ Mean Square $^{(1)}$} \\
\cline { 3 - 7 } & & E & FA & SDM & LDM & RDM & TSM \\
\hline $\begin{array}{l}\text { Hydric Restriction } \\
\text { Residue }\end{array}$ & 3 & $119.2^{*}$ & $3.59^{*}$ & 0.97 NS & $19.24^{*}$ & 2.02 NS & $18.77^{*}$ \\
\hdashline CV $(\%)$ & 12 & & & & & & \\
\hline
\end{tabular}

Note. ${ }^{(1)}$ Mean Square: ${ }^{*}$ and NS: Significant and non-significant, respectively by F test to 5\% level of probability; VF: Variance Factors; DF: Degree of Freedom; CV: Coefficient of Variation. 


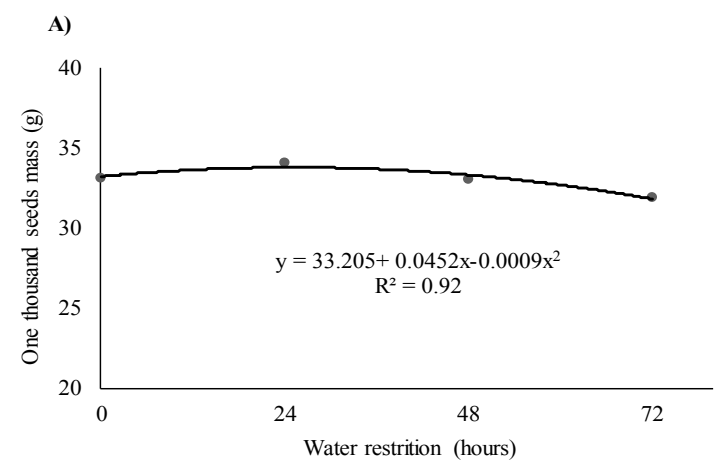

C)

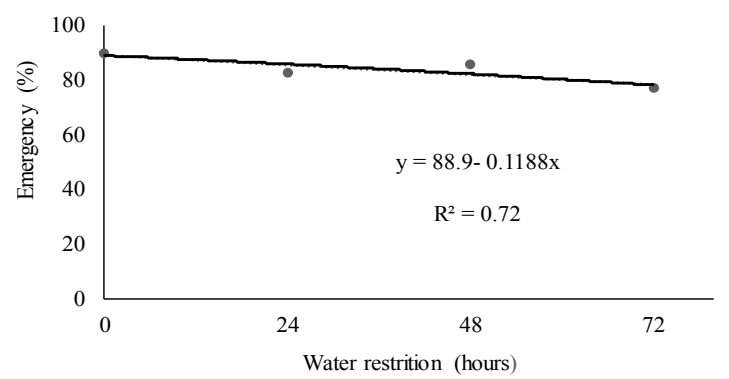

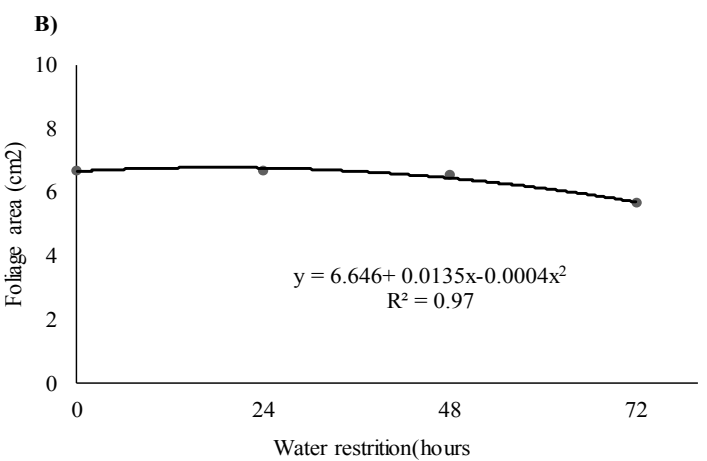

D)

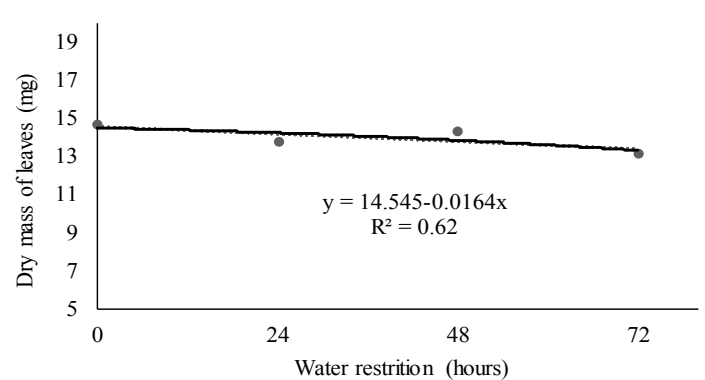

Figure 1. Regressions for rice thousand seeds mass (experiment 1), foliage area, field emergence and leave dry mass in relation to water restriction period

At the variance analysis (Table 2), it is observed that only the variable TSM obtained significant effects in the different water restriction levels, while at others variables did not demonstrated effect on the hydric restriction levels.

The results for field emergence and leaf area did not present significant difference between the hydric restriction levels. The data obtained for SDM, LDM and RDM were not affected by hydric restrictions levels.

Table 2. Análise de variância do experimento 2 (Soja) para o fator época de restrição hídrica para as variáveis de Emergência (E), Área foliar (AF), Massa seca da parte aérea (MSPA), massa seca das folhas (MSF) e massa seca da raiz (MSR) e Massa de mil sementes (MMS)

\begin{tabular}{|c|c|c|c|c|c|c|c|}
\hline \multirow{2}{*}{ VF } & \multirow{2}{*}{$\mathrm{DF}$} & \multicolumn{6}{|c|}{ Mean square $^{(1)}$} \\
\hline & & Emergence & Foliage Area & SDM & FDM & RDM & TSM \\
\hline Hydric restriction & 3 & $6 \mathrm{NS}$ & $4.9 \mathrm{NS}$ & $264.5 \mathrm{NS}$ & $29.8 \mathrm{NS}$ & $48.9 \mathrm{NS}$ & $9743.9^{\prime}$ \\
\hline Residue & 12 & & & & & & \\
\hline $\mathrm{CV}(\%)$ & & 5.56 & 13.4 & 11.5 & 8.8 & 13.8 & 8.0 \\
\hline
\end{tabular}

Note. ${ }^{(1)}$ Mean Square: ${ }^{*}$ and NS: Significant and non-significant, respectively by F test to $5 \%$ level of probability; VF: Variance Factors; DF: Degree of Freedom; CV: Coefficient of Variation.

At the Figure 2, it is possible to observe that the TSM was negatively influenced and had a linear tendency as the water restriction time increased. 


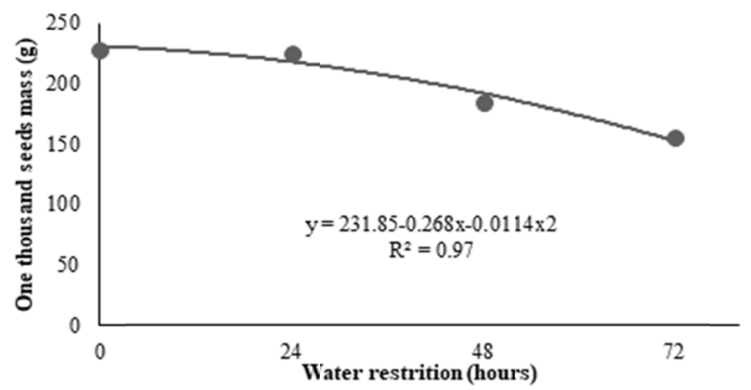

Figure 2. Regression for soybean thousand seeds mass (experiment 2) in relation to hydric restriction period

The presence of esterase isoenzymes bands (Figure 3), manifested with the same intensity in all soybean treats, not presenting difference of the isoenzyme expression in the treat. Although, the rice seeds analysis detected differences among treat bands, being T0 without presence of the isoenzyme, T1 with the presence of the isoenzyme and $\mathrm{T} 2$ and $\mathrm{T} 3$ band with more accentuate presence.

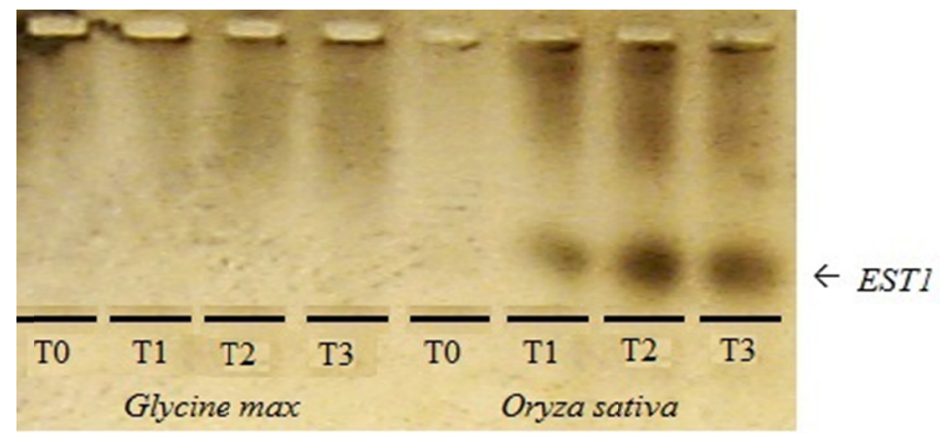

Figure 3. Presence of esterase isoenzymes bands in diferente levels of hydric restriction; T0: zero hours of hydric restriction; T1: 24 hours of hydric restriction; T2: 48 hours of hydric restriction; T3: 72 hours of hydric restriction of soybean seeds (experiment 2 ) and rice seeds (experiment 1), respectively

The negative effects caused by the hydric restriction accentuate if occurs in the reproductive stage, since the first flower until the seeds development, what can directly affect the thousand seeds mass (Aumonde et al, 2017). In study present by Bezerra et al. (2010), it was evidenced decrease in the mass of sesame seeds when submitted to different gradients of hydric availability.

In relation to the physiologic quality, similar results were obtained by (Peres, 2017), where presented variations of the hydric stress effect when compared to the physiologic quality of seeds between the rice produced in irrigated and non-irrigated systems, in two crop seasons, where the germination, vigor and seedlings dry matter were lower in rice plants produced in non-irrigated system.

Evaluating the effects of the hydric restriction in rice seeds, it is noted that the three stress levels, gradually, occasioned direct or indirect effects in the emergence characters, thousand seeds mass, foliage area and leaves dry matter. The 72 hours restriction level affected the most the seeds quality, being a result that can be expected in rice produced in high lands (Peres, 2017).

For field emergence, in study realized by Tavarel et al. (2013a), it was evidenced similar results, where the means obtained from soybean seeds produced under hydric restriction in the vegetative period, did not present significance for the different hydric regimes, same as found by Pedroso et al. (2009) on emergence and viability in coffee seeds. Plenty times the seeds vigor is subject to environmental conditions in the maturing moment.

For the variable leaf area, different results were found by Tavares (2013b), when testing high and low vigor seeds obtained difference of leaf area within the same vigor level. Although, it was observed differences among the treats with hydric deficit, being the period of 11 to 20 days after emergence superior to the other hydric deficit treats. Also, it is possible to affirm that there was no effect of seeds vigor in the variable shoot dry matter. 
For the thousand seeds mass, in study conducted by Freitas et al. (2013), was not evidenced losses in the thousand seeds mass of Caupí common beans, when produced until 22 days of non-irrigation, differing from results obtained by the present study.

The behavior of soybean seeds was not directly affected under different stress levels, it was only verified a negative effect in the variable thousand seeds mass and more intensified at the level of 72 hours of water restriction. It can induce to a new and more profound study, with the goal to verify the effects of the reduction of the seeds mass in their physiologic quality.

\section{Conclusions}

It was verified that as the hydric restriction hours increase, at the rice grains filling, the physiologic quality is affected, being that the higher effect occurred at 72 hours of restriction. While at the soybean seeds production it was not verified such effects, only the thousand seeds mass was not negatively affected. This research discovered the possible negative effects that can occurs in the quality of rice seeds, when exposed to hydric deficiency in dry lands, while for soybean seeds it can be relative, opening new cases to be studied. This study will support to supply information in order to repair the hydric restriction during critical stages in the seeds formation; as well will supply information to the researcher as reference for future researches on the effects of hydric restriction for the formation of high quality seeds.

\section{Acknowledgements}

To Coordenação de Aperfeiçoamento de Pessoal de Nível Superior (CAPES) and the Conselho Nacional de Desenvolvimento Científico e Tecnológico (CNPq) for the scholarship granted.

\section{References}

Ageitec (Agência Embrapa de Informação Tecnológica). (2018). Árvore de conhecimento arroz. Goiás: Agência Embrapa de Informação Tecnológica. Retrieved from http://www.agencia.cnptia.embrapa.br/gestor/arroz/ arvore/CONT000fe 75wint02wx5eo07qw4xeclygdut.html

Artigiani, A. C. C. A., Crusciol, C. A. C., Arf, O., Alvarez, R. C. F., \& Nascente, A. S. (2012). Produtividade e qualidade industrial do arroz de terras altas em função da disponibilidade hídrica e adubação. Pesquisa Agropecuária Tropical, 42(3), 340-349. https://doi.org/10.1590/S1983-40632012000300011

Aumonde, T. Z., Pedó, T., Martinazzo, E. G., \& Villela, F. A. (2017). Estresses ambientais e a produção de sementes: ciência e aplicação (p. 159). Pelotas: Cópias Santa Cruz.

Ávila, M. R., Braccini A. L., Scapim C. A., Mandarino J. M. G., Albrecht L. P. E., \& Filho P. S. V. Componentes do rendimento, teores de isoflavonas, proteínas, óleo e qualidade de sementes de soja. Revista Brasileira de Sementes, 3(29), 111-127.

Bezerra, S. A., Dantas Neto, J., Azevedo, C. A. V., Silva, M. B. R., \& Silva, M. M. (2010). Produção do gergelim cultivado sob condições de estresse hídrico e diferentes doses de adubação. Engenharia Ambiental-Espirito Santo do Pinhal, 7(3), 156-165.

Bonfim-Silva, E. M., Silva, T. J. A., Cabral, C. E. A., Kroth, B. E., \& Rezende, D. (2011). Desenvolvimento inicial de gramíneas submetidas ao estresse hídrico. Revista Caatinga, 24(2), 180-186.

Brasil, Ministério da Agricultura, Pecuária e Abastecimento. (2009). Regras para Análise de Sementes (p. 395). Secretaria de Defesa Agropecuária. Brasília: MAPA/ACS.

Catuchi, T. A., Guidorizzi, F. V. C., Guidorizi, K. A., Barbosa, A. M., \& Souza, G. M. (2012). Respostas fisiológicas de cultivares de soja à adubação potássica sob diferentes regimes hídricos. Pesquisa Agropecuária Brasileira, 47(4), 519-527. https://doi.org/10.1590/S0100-204X2012000400007

Costa, R. C. L., Lobato, A. K. S., Oliveira Neto, C. F., Maia, P. S. P., Alves, G. A. R., \& Laughinghouse, H. D. (2008). Biochemical and physiological responses in two Vigna unguiculata (L.) Walp. Cultivar Sunderwater Stress, 7(1), 98-101. https://doi.org/10.3923/ja.2008.98.101

CQFS-RS/SC (Comissão de química e fertilidade do solo RS/SC). (2004). Manual de adubação e de calagem para o Estado do Rio Grande do Sul e Santa Catarina (p. 400). Porto Alegre, SBCS/Núcleo Regional Sul, UFRGS.

Embrapa. (1997). Centro Nacional de Pesquisa de Solos. Manual de métodos de análise de solo (2nd ed., p. 212). Ver. Atual. Rio de Janeiro: EMBRAPA/CNPS. 
Fehr, W. R., \& Caviness, C. E. (1977). Stages of soybean development (p. 11). Ames, Iowa: Iowa State University of Science and Technology, Cooperative Extension Service.

Fioreze, S. L., Pivetta, L. G., Fano, A., Machado, F. R., \& Guimarães, V. F. (2011). Comportamento de genótipos de soja submetidos a déficit hídrico intenso em casa de vegetação. Revista Ceres, 58(3), 342-349. https://doi.org/10.1590/S0034-737X2011000300015

Freitas, R. M. O., Torres, S. B., Nogueira, N. W., Leal, C. C. P., \& Farias, R. M. (2013). Produção e qualidade de sementes de feijão-caupi em função de sistemas de plantio e estresse hídrico. Pesquisa Agropecuária Tropical, 43(4), 370-376. https://doi.org/10.1590/S1983-40632013000400009

Lobato, A. K. S., Oliveira, N. C. F., Costa, R. C. L., Santos Filho, B. G., Cruz, F. J. R., \& Laughinghouse, I. V. H. D. (2008). Biochemical and physiological behavior of Vigna unguiculata (L.) Walp. Under water stress during the vegetative phase. Asian Jornal Plant Science, 7(1), 44-49. https://doi.org/10.3923/ajps.2008. 44.49

Miorini, T. J. J., Saad, J. C. C., \& Menegale, M. L. (2011). Supressão de agua em diferentes fases fenológicas do feijoeiro (Phaseolus vulgaris L.). Irriga, Botucatu, 16(4), 360-368. https://doi.org/10.15809/irriga.2011 v16n4p360

Pedroso, T. Q., Scalco, M. S., Carvalho, M. L. M., Resende, C. A., \& Otoni, R. R. (2009). Qualidade de sementes de cafeeiro produzidas em diferentes densidades de plantio e regimes hídricos. Coffee Science, 4(2), 155-164.

Peres A. R. (2017). Variação hídrica e fontes de nitrogênio em cultivares de arroz de terras altas: Produção e qualidade fisiológica de sementes (Tese doutorado, Universidade estadual de São Paulo, Ilha solteira).

Scandalios, J. G. (1969). Genetic control of multiple molecular forms of enzymes in plants: A review. Biochemical Genetics, 3, 37-39. https://doi.org/10.1007/BF00485973

Szareski, V. J., Carvalho, I. R., Demari, G. H., Souza, V. Q., Rosa, T. C., Villela, F. A., ... Aumonde, T. Z. (2018). Multivariate index of soybean seed vigor: A new biometric approach applied to the effects of genotypes and environments. Journal of Seed Science, 40(4), 396-406. https://doi.org/10.1590/2317-1545 v40n4198333

Szareski, V. J., Carvalho, I. R., Rosa, T. C., Dellagostin, S. M., Pelegrin, A. J., Barbosa, M. H., ... Pegoraro, C. (2018). Oryza wild species: An alternative for rice breeding under abiotic stress conditions. American Journal of Plant Sciences, 9, 1093-1104. https://doi.org/10.4236/ajps.2018.96083

Szareski, V. J., Carvalho, I. R., Kehl, K., Levien, A. M., Nardino, M., Dellagostin, S. M., ... Aumonde, T. Z. (2018). Evaluation of the adaptability and stability of wheat genotypes using a phenotypic index of seed vigor. Pesquisa Agropecuária Brasileira, 53(6), 727-735. https://doi.org/10.1590/s0100-204x20180006 00009

Tavares, L. C., Rufino, C. de A., Brunes, A. P., Tunes, L. M., Barros, A. C. S. A., \& Peske, S. T. (2013a). Desempenho de sementes de soja sob deficiência hídrica: rendimento e qualidade fisiológica da geração F1. Ciencia Rural, Santa Maria, 43(8), 1357-1363. https://doi.org/10.1590/S0103-84782013000800003

Tavares, L. C., Rufino, C. A., Tunes, L. M., \& Barros, A. C. S. A. (2013b). Rendimento e qualidade de sementes de soja de alto e baixo vigor submetidas ao déficit hídrico. Interciência, 38(8).

\section{Copyrights}

Copyright for this article is retained by the author(s), with first publication rights granted to the journal.

This is an open-access article distributed under the terms and conditions of the Creative Commons Attribution license (http://creativecommons.org/licenses/by/4.0/). 